\title{
In memory of Professor Zygmunt Brogowski (1926-2021)
}

\author{
Józef Chojnicki, Wojciech Kwasowski \\ Warsaw University of Life Sciences - SGGW, Institute of Agriculture, Department of Soil Science, 159 Nowoursynowska Str., 02-776 Warsaw, \\ Poland \\ * e-mail: jozef_chojnicki@sggw.edu.pl
}

Professor Zygmunt Brogowski passed away on February 20, 2021 at the age of 95. He was born on January 11, 1926 in Bełżec, Tomaszów Lubelski district. In 1948 He finished the Secondary School of Agriculture and Breeding in Dobrocin, and in 1953 he obtained a master's degree at the Faculty of Agriculture of the Warsaw University of Life Sciences-SGGW (WULS-SGGW) in Warsaw. Throughout his professional life, he was associated with the Department of Soil Science at the Faculty of Agriculture of the WULSSGGW in Warsaw, where he was employed on January 1, 1952. In 1962, he received PhD degree in agricultural and forestry sciences on the basis of the dissertation entitled "Organic and mineral phosphorus in some

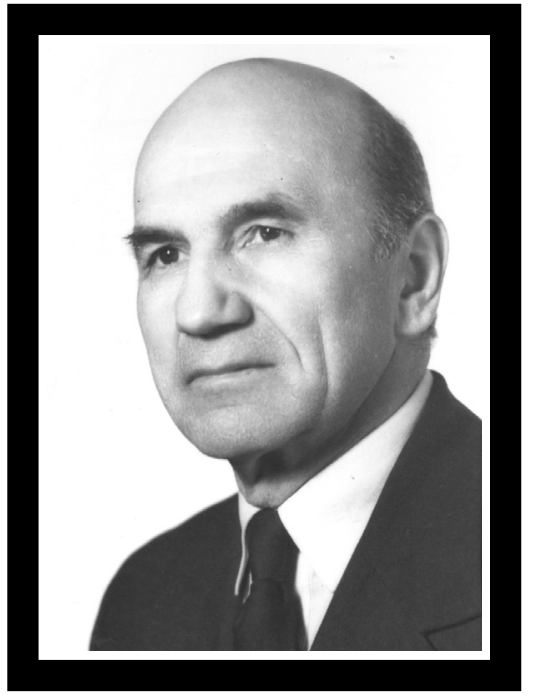
He was the author or co-author of about 140 scientific papers, including 70 peerreviewed. He promoted 7 doctors, 62 masters, made 25 reviews for the title of professor and the academic degree of habilitated doctor, as well as reviewed many doctoral dissertations, publications, monographs and textbooks.

He had very great achievements in practically important research for environmental protection, which resulted in the development of many recycling technologies enabling the secondary, fertilizing use of organic and mineral waste. Thanks to the Professor's very good cooperation with the economic environment, many of the developed technologies were practically implemented. In the years 1957-1976 (with breaks) he was sandy soils of Poland", carried out under the guidance of prof. Arkadiusz Musierowicz and in 1967 was habilitated after submission of the dissertation "Binding of calcium, magnesium, potassium and sodium in some types of soil”. In 1978 he received position of associate professor and full professor in 1990. He developed his research skills during many domestic and foreign research internships. In 1958, he completed a 6week research internship in the field of soil humus research at the Institute of Dokuchayev in Moscow under the supervision of prof. M.M. Kononowa, in 1959/60 one-year internship at the Department of Soil Science and Fertilization at the Michigan State University of the USA in East Lansing under the supervision of professors R.L. Cook, K. Lawton, and M. Mortland and in 1967/68 he completed a one-year research internship at the Department of Soil Science and Fertilization at the Agricultural University of Wageningen under the supervision of L. Schuffelen, H.G. Bolt and Van Diesta.

Professor Z. Brogowski initiated and pursued ambitious and at the same time difficult research directions. The main ones included the application of mathematical modeling in the study of soils, the occurrence and transformation of clay minerals in soils, the properties of soil granulometric fractions, the ionic balance of crops and forest plants, and soil protection. a scientific consultant for soil classification and cartography in the Łódź and Białystok voivodeships and in the years 1955-1958 he conducted classes at courses organized by the Ministry of Agriculture in the field of soil classification and cartography. He was the co-author of the soil map of Poland in the scale of 1 : 300,000 and the table of land classes for the area of the Suwałki Lake District, on the basis of which the agricultural land valuation was carried out in this region.

Professor conducted all kinds of classes at many faculties of the WULS-SGGW, but mainly with students of Economics, Agriculture and Land Reclamation faculties. Also, in the years 1980-1990 he conducted classes in soil science for students of the Faculty of Agriculture at the Higher School of Agriculture and Pedagogy in Siedlce, and also in 1996-2017 classes in soil science for students at the Higher School of Economics and $\mathrm{Hu}-$ manities in Skierniewice. His classes were conducted at a very high level, he was able to convey knowledge to his students in an understandable and interesting way. He was a co-author of two scripts and a co-translator of a Russian textbook and two English textbooks into Polish.

Professor Z. Brogowski had very great achievements in organizational activity. He was the Vice-Dean in the years 1969- 
1975 and the Dean in the years 1976-1978 and 1981-1987 of the Agricultural Faculty of the WULS-SGGW. He was awarded the title of Honorary Dean by the Council of the Agriculture Faculty. In 1979, he organized the first doctoral studies at the Faculty of Agriculture, serving as the head of these studies until 1982 and again from 1988 to 1996 . He was the author of doctoral study programs and conducted seminars for doctoral students. In the years 1954-1967 he was the tutor of the Scientific Society "Soil Science" founded by students of the Horticulture and Agriculture faculties. In the years 1969-1987 he was a member of many senate committees, including Personnel Development and Promotion, Awards and Decorations, and in 1987-1996 on the History of the WULS-SGGW. In the years 1963-1967 he was the secretary of the Committee of Soil Science and Agricultural Chemistry at the $5^{\text {th }}$ Department of the Polish Academy of Sciences, and in the years 1984-1995 he was a member of this Committee. Professor was the initiator and creator of direct cooperation between the Department of Soil Science of the WULS-SGGW with the Department of Soil Science at the Moscow Timiryazev Agricultural Academy, which was carried out in 1972-2000 and with the Department of Soil Science at Ain Shams University in Cairo, which was active in 1980-2011.

Professor made a great contribution to the functioning and development of the Soil Science Society of Poland (SSSP). He was its member from 1952, and from 2002 he was a member of the International Union of Soil Science. He began his many years of activity in the Warsaw Branch of SSSP from the moment of its inception in 1955, serving as the chairman of the Branch in the years 1971-1974 and 1978-1983. He was active in the Main Board of SSSP as its member in 1955-1959 and as its treasurer in 1964-1967, 1988-1991 and 1991-1995. He was the initiator and co-organizer of many important seminars and scientific conferences. For his activity in the SSSP, he was awarded the Golden Badge of the Soil Science Society of Poland, the medal "75 years of the Soil Science Society of Poland", and in 2015 he was awarded the title of Honorary Member of the Society. From 1954 he was also a member of the Botanical Society, from 1986 the Warsaw Scientific Society, and in 1980-1995 he belonged to the Mineralogical Society.

For the overall activity, he was honored, among others, Knight's Cross of the Order of Polonia Restituta, Gold and Silver Cross of Merit, Medal of the National Education Commission, Badge "Meritorious Agricultural Worker", Gold Badge of Honor "For Merits for the Warsaw University of Life Sciences", Medal of the Agronomic Institute in Marymont and numerous awards of the Rector of the Warsaw University of Life Sciences.

Not only an outstanding scientist, educator, organizer of science and teaching has passed away from us. Prof. Brogowski was a righteous, disinterested and noble man, a reliable friend, who created an atmosphere full of kindness, trust and efficiency in the everyday life of the academic community. His rich scientific achievements contributed greatly to the development of soil science and significantly influenced the scientific development of many generations of soil scientists from Warsaw University of Life Sciences and Poland. He will remain in our memory as an example of an academic teacher who was very demanding, firm and consistent in conducting scientific research and in the matters of ethics of the scientist and academic teacher. Thanking the Professor for many years of fruitful cooperation and the effort put into our education, we promise to continue and develop his scientific and creative thoughts.

The most important scientific articles published by Professor Zygmunt Brogowski are listed below. The articles marked with the letters PL were published in Polish language with abstracts and summaries in English.

1. Brogowski Z., Chojnicki J., 2020. Distribution of phosphorus in granulometric fractions of Cambisol developed from morainic loam. J. Elem. 25(1): 181-191.

2. Brogowski Z., Chojnicki J., 2019. Sorption properties of separate granulometric fractions in Haplic Cambisol. International Agrophysics 33, 1: 137-143.

3. Brogowski Z., Chojnicki J., 2019. Sorption properties of granulometric fractions in Haplic Cambisol developed from boulder loam. Soil Science Annual - Roczniki Gleboznawcze 70(2): 147-157.

4. Brogowski Z., Kwasowski W., 2015. An attempt of using soil grain size in calculating the capacity of water unavailable to plants. Soil Science Annual - Roczniki Gleboznawcze 66(1): 21-28.

5. Brogowski Z., Kwasowski W., 2014. Contribution of granulometric fractions in phosphorus distribution in old alluvial soil. Soil Science Annual - Roczniki Gleboznawcze 65(4): 150-155.

6. Brogowski Z., Kwasowski W., Madyniak R., 2014. Calculating particle density, bulk density, and total porosity of soil based on its texture. Soil Science Annual - Roczniki Gleboznawcze 65(4): 139-149.

7. Brogowski Z., Czępińska-Kamińska D., 2013. The state of ionic balance in selected plant species from natural habitats of the Piska Primeval Forest (NE Poland). Soil Science Annual - Roczniki Gleboznawcze 64(4): 151-157.

8. Brogowski Z., Chojnicki J., 2013. Distribution of organic matter and nitrogen in the particle size fractions of genetic horizons in Dystric Cambisols in the Kabacki Forest. Sylwan 157, 6: 470-480. (PL).

9. Brogowski Z., Kwasowski W., 2012. Distribution of organic matter in the particle size fractions of lateritic soil (Plinthosol). Soil Science Annual - Roczniki Gleboznawcze 63(4): 9-15.

10. Dmuchowski W., Brogowski Z., Baczewska A., 2011. Evaluation of vigour and health of "street" trees using foliar ionic status. Polish Journal of Environmental Studies 20, 2: 489-496.

11. Brogowski Z., Uziak S., Komornicki T., 2010. Quantitative magnesium distribution in granulometric fractions of some soils. Polish Journal of Soil Science 43(2): 151-164.

12. Brogowski Z., Uziak S., Komornicki T., 2010. Quantitative distribution of total calcium in granulometric fractions of certain soils of Poland. Polish Journal of Soil Science 43(1): 21-35.

13. Brogowski Z., Uziak S., Komornicki T., 2010. Influence of the geological origin of soil materials and pedogenic processes on the chemical composition of the clay fraction. Roczniki Gleboznawcze - Soil Science Annual 61(4): 26-39. (PL)

14. Brogowski Z., Kozanecka T., 2009. Impact of certain genetic horizons of soil on the yield and chemical composition of westerwold ryegrass (Arrhenatherum elatius L.). Polish Journal of Soil Science 42(1): 77-88.

15. Kozanecka T., Brogowski Z., Kisiel M., Stępień W., 2009. Mobility of exchangeble cations in soils from long term field experiments in Skierniewice. Polish Journal of Soil Science 42(1): 1-14.

16. Brogowski Z., Uziak S., Komornicki T., 2009. Distribution of potassium in granulometric soil fractions. Polish Journal of Soil Science 42(1): 53-68.

17. Brogowski Z., Kwasowski W., 2009. Phosphorus adsorption by organic and mineral parts of soil. Roczniki Gleboznawcze - Soil Science Annual 60(1): 12-21. (PL) 
18. Brogowski Z., Uziak S., Komornicki T., 2008. Total aluminium content in the granulometric fraction of soils originating from various geological formations. Polish Journal of Soil Science 41(1): 51-60.

19. Brogowski Z., Okołowicz M., 2008. Balance of organic carbon and nitrogen in the granulometric fractions of alluvial soil. Roczniki Gleboznawcze - Soil Science Annual 59(3/4): 41-50. (PL)

20. Brogowski Z., Uziak S., Komornicki T., 2007. Distribution of total iron in granulometric fractions of soils derived from various parent materials. Polish Journal of Soil Science 40(2): 147-163.

21. Kozanecka T., Czarnowska K., Brogowski Z., Kwasowski W., 2006. Content of microelements in selected herbs from natural meadows. Polish Journal of Environmental Studies 15, 2a, P. 2: 385-389.

22. Brogowski Z., Chojnicki J., 2005. Distribution of total potassium in separate granulometric fractions of brown soil. Roczniki Gleboznawcze - Soil Science Annual 56(1/2): 27-39. (PL)

23. Brogowski Z., Siewert H., Keplinger D., 2005. Feeding and growth responses of bluegill fish (Lepomis macrochirus) at various $\mathrm{pH}$ levels. Polish Journal of Environmental Studies 14, 4: 517-519.

24. Brogowski Z., Renman G., 2004. Characterization of opoka as a basis for its use in wastewater treatment. Polish Journal of Environmental Studies 13, 1: 15-20.

25. Brogowski Z., Gawrońska-Kulesza A., Kozanecka T., 2002. Red clover as a receptor of $\mathrm{CO}_{2}$ from the atmosphere and some compounds from soil. Polish Journal of Environmental Studies 11, 6: 625-629.

26. Gworek B., Brogowski Z., Degórski M., Wawrzoniak J., 2000. Changes of physico-chemical properties of some soils in Białowieża National Park. Roczniki Gleboznawcze - Soil Science Annual 51(1/2): 87-99. (PL)

27. Brogowski Z., Czarnowska K., Chojnicki J., Pracz J., Zagórski Z., 2000. Influence of salt stress on chemical composition of trees leafs from Łodź city area. Roczniki Gleboznawcze - Soil Science Annual 51(1/2): 17-28. (PL)

28. Brogowski Z., Borzyszkowski J., Gworek B., Ostrowska A., Porębska G., Sienkiewicz J., 1997. Soils characteristics of deforested region of the Izerskie Mountains. Roczniki Gleboznawcze - Soil Science Annual 48(1/2): 111-124. (PL)

29. Gworek B., Brogowski Z., Jeske K., 1996. Influence of the synthetic zeolites on heavy metals uptake by lettuce from soil polluted by sewage sludge. Roczniki Gleboznawcze - Soil Science Annual 47(1/2): 47-53. (PL)

30. Okołowicz M., Brogowski Z., 1996. Energetic compounds in the granulometric fractions of some soils. Roczniki Gleboznawcze - Soil Science Annual 47(supl.): 31-41. (PL)

31. Brogowski Z., 1996. The total content of elements in grain $<0,1 \mathrm{~mm}$ in diameter separated from gley-podzolic soil. Roczniki Gleboznawcze - Soil Science Annual 47(supl.): 9-21. (PL)

32. Brogowski Z., Mazurek A., 1990. Mineral composition of soil grains of $<0.02 \mathrm{~mm}$ in diameter in brown soil developed from boulder loam. Roczniki Gleboznawcze - Soil Science Annual 41(1/2): 5-21. (PL)

33. Brogowski Z., 1990. An attempt of calculation of some physical properties of soils on the basis of granulometric analysis. Roczniki Gleboznawcze - Soil Science Annual 41(3/4): 17-28. (PL)

34. Brogowski Z., Mazurek A., 1986. Mineral composition of fractions $<0.02 \mathrm{~mm}$ of alluvial soil. Roczniki Gleboznawcze - Soil Science Annual 37(4): 9-22. (PL)

35. Brogowski Z., 1986. Skład chemiczny ściółek leśnych zachodniej części KPN. (w) Wpływ działalności człowieka na środowisko glebowe w Kampinoskim Parku Narodowym (1984-1985), Wyd. SGGW-AR, Warszawa: 103-122. (PL)

36. Brogowski Z., Dobrzański B., Kocoń J., Okołowicz M., 1986. Morfologia, struktura i ultrastruktura ziarn pyłu gleb piaskowych Kampinoskiego Parku Narodowego. (w) Wpływ działalności człowieka na środowisko glebowe Kampinoskiego Parku Narodowego (1984-1985), Wyd. SGGW-AR, Warszawa: 171-178. (PL)

37. Brogowski Z., Okołowicz M., 1986. Rozmieszczenie związków fosforu w glebie kopalnej wytworzonej z holoceńskich piasków wydmowych. (w) Wpływ działalności człowieka na środowisko glebowe w Kampinoskim Parku Narodowym (1984-1985), Wyd. SGGW-AR, Warszawa: 179-187. (PL)

38. Konecka-Betley K., Brogowski Z., Okołowicz M., 1985. Distribution of phosphorus compounds in fossil soils developed from late pleistocenic dune sands at Cięciwa. Roczniki Gleboznawcze - Soil Science Annual 36(2): 75-84. (PL)

39. Brogowski Z., Okołowicz M., Pęczek H., 1985. Carbon and nitrogen in granulometric fractions of sandy soils. Roczniki Gleboznawcze - Soil Science Annual 36(2): 21-28. (PL)

40. Brogowski Z., Kocoń J., 1984. Morphology of surface of sand grains from different genetic horizons of brown soil developed from heavy loam. Roczniki Gleboznawcze - Soil Science Annual 35(1): 115-124. (PL)

41. Kowalkowski A., Brogowski Z., 1983. Features of cryogenic environment in soils of continental tundra and arid steppe on the southern Khangai slope under electron-microscope. Catena 10(3): 199-205.

42. Brogowski Z., Grylewicz M., Pęczek H., 1983. Węgiel i azot we frakcjach mechanicznych gleb bielicowych Kampinoskiego Parku Narodowego. (w) Wpływ działalności człowieka na środowisko glebowe w Kampinoskim Parku Narodowym, Wyd. SGGW-AR, Warszawa: 59-72. (PL)

43. Brogowski Z., Mazurek A., 1981. Differentiation of clay minerals in particular mechanical fractions of soil. Roczniki Gleboznawcze - Soil Science Annual 32(3): 193-205. (PL)

44. Brogowski Z., Dobrzański B., Kocoń J., 1979. Morphology of natural zeolites occuring in soil as determined by electron-microscopy. Bulletin De L Academie Polonaise des Sciences-Serie Des Sciences De La Terre 27, 1-2: 115-\&

45. Brogowski Z., Czerwiński Z., Tuszyński M., 1975. Effect of NaCl emission on soils and plants in the vicinity of the Wieliczka salt works. Roczniki Gleboznawcze - Soil Science Annual 26(3): 259-276. (PL)

46. Dobrzański B., Borek S., Brogowski Z., Czarnowska K., Czerwiński Z., Kępka M., Konecka-Betley K., Kuźniarowa A., Łakomiec J., Święcicki Cz., 1973. Typologia i właściwości gleb wytworzonych z gliny zwałowej zlodowacenia środkowopolskiego. Rocz. Nauk. Rol. 151-D: 1-75. (PL)

47. Musierowicz A., Brogowski Z., Czarnowska K., Czerwiński Z., KoneckaBetley K., Król H., Kuźnicki F., Leszczyńska E., Sytek J., Święcicki C., Tuszyński M., Kobylińska J., 1967. Typology and properties of soils from boulder loams. Part I. Brown and pseudopodzolic forest soils. Roczniki Gleboznawcze - Soil Science Annual 17: 29-129. (PL)

48. Brogowski Z., 1966. Organic and mineral phosphorus in some sandy soils of Poland. Roczniki Gleboznawcze - Soil Science Annual 16(1): 209-240. (PL)

49. Brogowski Z., 1966. Methods of determining mineral and organic phosphorus in soils. Roczniki Gleboznawcze - Soil Science Annual 16(1): 193-208. (PL)

50. Musierowicz A., Brogowski Z., 1963. Preliminary studies on rate of exchangeable cations release from the sorption complex of sandy soils. Roczniki Gleboznawcze - Soil Science Annual 13(1): 3-16. (PL)

51. Brogowski Z., 1961. Liberation of cations from the sorption complex of sand soils. Roczniki Gleboznawcze - Soil Science Annual 10(dod.): 680-683. (PL)

52. Musierowicz A., Olszewski Z., Brogowski Z., Chlipalska E., KoneckaBetley K., Kępka M., Król H., Kuźnicki F., Leszczyńska E., Skorupska T., Święcicki Cz., Tuszyński M., 1960. Gleby województwa łódzkiego. Rocz. Nauk Rol. T 86-D: 1-389. (PL)

53. Musierowicz A., Brogowski Z., Skorupska T., 1960. Materials to the knowledge of the organic compounds in Polish soils. Roczniki Gleboznawcze - Soil Science Annual 9(1): 103-130. (PL)

54. Musierowicz A., Brogowski Z., 1958. The method of Gigel applied to the determination of mineral and organic phosphorus in light soils. Roczniki Gleboznawcze - Soil Science Annual 7(dod.): 181-184. (PL) 


\section{Wspomnienie Prof. dr hab. Zygmunta Brogowskiego (1926-2021)}

Profesor Zygmunt Brogowski zmarł 20 lutego 2021 r. w wieku 95 lat. Urodził się 11 stycznia 1926 r. w Bełżcu, pow. Tomaszów Lubelski. W 1948 r. ukończył Gimnazjum i Liceum Rolniczo - Hodowlane w Dobrocinie, a w 1953 r. uzyskał tytuł magistra na Wydziale Rolniczym Szkoły Głównej Gospodarstwa Wiejskiego (SGGW) w Warszawie. Przez całe życie zawodowe był związany z Katedrą Gleboznawstwa Wydziału Rolniczego SGGW w Warszawie, w której został zatrudniony 1 stycznia 1952 r. W 1962 r. otrzymał stopień doktora nauk rolniczo-leśnych na podstawie rozprawy pt. „Fosfor organiczny i mineralny w niektórych glebach piaskowych Polski”, wykonanej pod kierunkiem prof. dr hab. Arkadiusza Musierowicza, a w 1967 r. stopień naukowy doktora habilitowanego w zakresie gleboznawstwa na podstawie rozprawy habilitacyjnej: „Wiązanie wapnia, magnezu, potasu i sodu w niektórych rodzajach gleb". W 1978 r. otrzymał tytuł profesora nadzwyczajnego, a w 1990 r. profesora zwyczajnego. Swoje umiejętności prowadzenia badań naukowych rozwinął podczas wielu krajowych i zagranicznych staży naukowych. W roku 1958 odbył 6-tygodniowy staż naukowy w zakresie badań humusu glebowego w Instytucie im. Dokuczajewa w Moskwie pod kierunkiem prof. dr M.M. Kononowej, w 1959/60 r. roczny staż w Katedrze Gleboznawstwa i Nawożenia w Uniwersytecie Stanowym Michigan USA w East Lansing pod kierunkiem profesorów: R.L. Cook, K. Lawtona i M. Mortlanda oraz 1967/68 r. zrealizował roczny staż naukowy w Katedrze Gleboznawstwa i Nawożenia w Uniwersytecie Rolniczym Wageningen pod kierunkiem profesorów: L. Schuffelena i H.G. Bolta oraz Van Diesta.

Pan Profesor inicjował i realizował ambitne i zarazem trudne kierunki badań. Główne z nich obejmowały zastosowanie modelowania matematycznego w badaniu gleb, występowanie i przemiany minerałów ilastych w glebach, właściwości frakcji granulometrycznych gleb, równowagę jonową roślin uprawnych i leśnych oraz ochronę gleb. Był autorem lub współautorem około 140 prac naukowych, w tym 70 recenzowanych. Wypromował 7 doktorów, 62 magistrów, wykonał 25 recenzji na tytuł profesora i stopień naukowy dr habilitowanego oraz wielu prac doktorskich, publikacji, monografii i podręczników.

Miał bardzo duże osiągnięcia w badaniach o znaczeniu praktycznym dla ochrony środowiska, których efektem było opracowanie wielu technologii recyklingu umożliwiających wtórne, nawozowe wykorzystanie odpadów organicznych i mineralnych. Dzięki bardzo dobrej współpracy Profesora z otoczeniem gospodarczym wiele opracowanych technologii zostało praktycznie wdrożonych. W latach 1957-1976 (z przerwami) pełnił funkcję konsultanta naukowego ds. klasyfikacji i kartografii gleb na terenie województwa łódzkiego i białostockiego oraz w latach 1955-1958 prowadził zajęcia na kursach organizowanych przez Ministerstwo Rolnictwa z zakresu klasyfikacji i kartografii gleb. Był współautorem mapy gleb Polski w skali 1:300 000 oraz tabeli klas gruntów dla obszaru Pojezierza Suwalskiego, na podstawie której przeprowadzono w tym regionie bonitację gruntów rolniczych.

Pan Profesor prowadził wszystkiego rodzaju zajęcia na wielu wydziałach SGGW, jednak głównie ze studentami Wydziału
Ekonomiczno-Rolniczego i Wydziału Melioracji Wodnych. Również w latach 1980-1990 prowadził zajęcia z gleboznawstwa dla studentów Wydziału Rolniczego w Wyższej Szkole Rolniczo-Pedagogicznej w Siedlcach, a w latach 1996-2017 zajęcia z gleboznawstwa dla studentów w Wyższej Szkole EkonomicznoHumanistycznej w Skierniewicach. Jego zajęcia były prowadzone na bardzo wysokim poziomie, potrafił w sposób zrozumiały i interesujący przekazać wiedzę słuchaczom. Był współautorem dwóch skryptów i współtłumaczem na język polski podręcznika z języka rosyjskiego i dwóch podręczników z języka angielskiego.

Profesor Z. Brogowski miał bardzo duże osiągnięcia w działalności organizacyjnej. Był Prodziekanem w latach 1969-1975, Dziekanem w latach 1976-1978 i 1981-1987 Wydziału Rolniczego SGGW. Otrzymał tytuł Honorowego Dziekana nadany przez Radę Wydziału Rolniczego. W 1979 r. zorganizował pierwsze studia doktoranckie przy Wydziale Rolniczym, pełniąc funkcję kierownika tych studiów do 1982 r. i ponownie od 1988 do 1996 r. Był autorem programów studiów doktoranckich i prowadził seminaria dla doktorantów. W latach 1954-1967 pełnił funkcję opiekuna Koła Naukowego „Gleboznawców” założonego przez studentów Wydziału Ogrodniczego i Rolniczego. W latach 1969-1987 był członkiem wielu komisji senackich, w tym ds. Rozwoju Kadr i Awansów, ds. Nagród i Odznaczeń, a w latach 1987-1996 ds. Historii SGGW. W latach 1963-1967 był sekretarzem Komitetu Gleboznawstwa i Chemii Rolnej przy V Wydziale Polskiej Akademii Nauk, natomiast w latach 1984-1995 był członkiem tego Komitetu. Profesor był inicjatorem i twórcą bezpośredniej współpracy Katedry Gleboznawstwa SGGW z Katedrą Gleboznawstwa Akademii Rolniczej im. Timiriazewa w Moskwie, która była realizowana w latach 1972-2000 oraz z Katedrą Gleboznawstwa Uniwersytetu Ain Shams w Kairze, która miała aktywny charakter w latach 1980-2011.

Profesor miał duże zasługi w funkcjonowaniu i rozwoju Polskiego Towarzystwa Gleboznawczego (PTG). Był jego członkiem od 1952 r., a od 2002 roku Międzynarodowej Unii Gleboznawczej. Swoją wieloletnią działalność w Oddziale Warszawskim PTG rozpoczął od momentu jego powstania w 1955 r., pełniąc między innymi funkcję przewodniczącego Oddziału w latach 1971-1974 i 1978-1983. Aktywnie działał w Zarządzie Głównym PTG jako jego członek w latach 1955-1959 oraz jako jego skarbnik w latach 1964-1967, 1988-1991 i 1991-1995. Był inicjatorem i współorganizatorem wielu ważnych seminariów i konferencji naukowych. Za działalność w Polskim Towarzystwie Gleboznawczym został uhonorowany Złotą Odznaką PTG, medalem „75 lat Polskiego Towarzystwa Gleboznawczego”, a w 2015 r. otrzymał godność Honorowego Członka Towarzystwa. Był także od 1954 r. członkiem Towarzystwa Botanicznego, od 1986 r. Warszawskiego Towarzystwa Naukowego, a w latach 1980-1995 należał do Towarzystwa Mineralogicznego.

Za całokształt działalności został odznaczony, wyróżniony m.in. Krzyżem Kawalerskim Orderu Odrodzenia Polski, Złotym i Srebrnym Krzyżem Zasługi, Medalem Komisji Edukacji Narodowej, Odznaką „Zasłużony Pracownik Rolnictwa”, Złotą 
Odznaką Honorową „Za Zasługi dla SGGW”, Medalem Instytutu Agronomicznego w Marymoncie oraz licznymi nagrodami JM Rektora SGGW.

Odszedł od nas nie tylko wybitny uczony, pedagog, organizator nauki i nauczania, ale także prawy, bezinteresowny i szlachetny człowiek, niezawodny przyjaciel, który tworzył pełną życzliwości, zaufania i efektywności atmosferę w życiu codziennym społeczności akademickiej. Jego bogaty dorobek naukowy miał duży wkład w rozwój nauki o glebach oraz istotnie wpłynął na rozwój naukowy wielu pokoleń gleboznawców SGGW i Polski. Pozostanie w naszej pamięci jako wzór nauczyciela akademickiego, który był bardzo wymagający, stanowczy i konsekwentny w prowadzeniu badań naukowych oraz w sprawach etyki uczonego i nauczyciela akademickiego. Dziękując Panu Profesorowi za wieloletnią owocną współpracę oraz trud włożony w nasze wychowanie, obiecujemy kontynuować i rozwijać Jego naukowe, twórcze myśli. 